\title{
Whole-exome sequencing analysis on products of conception: A cohort study to evaluate clinical utility and genetic etiology for pregnancy loss
}

Chen Zhao, $\mathrm{PhD}^{1}$, Hongyan Chai, $\mathrm{PhD}^{1}$, Qinghua Zhou, $\mathrm{PhD}^{4}$, Jiadi Wen, $\mathrm{MD}, \mathrm{PhD}^{1}$, Uma M. Reddy, MD, $\mathrm{MPH}^{2}$, Rama Kastury, $\mathrm{DO}^{1}$, Yonghui Jiang, $\mathrm{MD}, \mathrm{PhD}^{1}$, Winifred Mak, $\mathrm{MD}, \mathrm{PhD}^{1,3}$, Allen E. Bale, MD, $\mathrm{PhD}^{1}$, Hui Zhang MD, $\mathrm{PhD}^{1}$, Peining $\mathrm{Li}, \mathrm{PhD}^{1}$

${ }^{1}$ Departments of Genetics, ${ }^{2}$ Obstetrics and Gynecology, Yale School of Medicine, New Haven, CT, USA; ${ }^{3}$ Department of Women's Health, Dell Medical School, The University of Texas at Austin, TX, USA; ${ }^{4}$ Biomedical Translational Research Institute, Jinan University, Guangzhou, China.

Correspondence: Winifred Mak (winifred.mak@ austin.utexas.edu), Allen E. Bale (allen.bale@yale.edu), Hui Zhang (hang.hui@yale.edu), Peining Li (peining.li@ yale.edu)

These authors contributed equally: Chen Zhao, Hongyan Chai 
medRxiv preprint doi: https://doi.org/10.1101/2020.07.19.20150144; this version posted July 20, 2020. The copyright holder for this preprint (which was not certified by peer review) is the author/funder, who has granted medRxiv a license to display the preprint in perpetuity.

All rights reserved. No reuse allowed without permission.

\begin{abstract}
Purpose: Pregnancy loss ranging from spontaneous abortion (SAB) to stillbirth can result from monogenic causes of Mendelian inheritance. This study evaluated the clinical application of whole exome sequencing (WES) in identifying the genetic etiology for pregnancy loss.
\end{abstract}

Methods: A cohort of 102 specimens from products of conception (POC) with normal karyotype and absence of pathogenic copy number variants were selected for WES. Abnormality detection rate (ADR) and variants of diagnostic value correlated with SAB and stillbirth were evaluated.

Results: WES detected six pathogenic variants, 16 likely pathogenic variants, and 17 variants of uncertain significance favor pathogenic (VUSfp) from this cohort. The ADR for pathogenic and likely pathogenic variants was $22 \%$ and reached $35 \%$ with the inclusion of VUSfp. The ADRs of SAB and stillbirth were $36 \%$ and $33 \%$, respectively. Affected genes included those associated with multi-system abnormalities, neurodevelopmental disorders, cardiac anomalies, skeletal dysplasia, metabolic disorders and renal diseases.

Conclusion: These results supported the clinical utility of WES for detecting monogenic etiology of pregnancy loss. The identification of disease associated variants provided information for follow-up genetic counseling of recurrence risk and management of subsequent pregnancies. Discovery of novel variants could provide insight for underlying molecular mechanisms causing fetal death.

Key Words: whole exome sequencing (WES), pregnancy loss, products of conception (POC), abnormality detection rate (ADR), genetic etiology

Running Title: Whole-exome sequencing analysis on products of conception 
medRxiv preprint doi: https://doi.org/10.1101/2020.07.19.20150144; this version posted July 20, 2020. The copyright holder for this preprint (which was not certified by peer review) is the author/funder, who has granted medRxiv a license to display the preprint in perpetuity.

All rights reserved. No reuse allowed without permission.

\section{INTRODUCTION}

The incidence of pregnancy loss from implantation to clinically recognized spontaneous abortions (SAB) was approximately $30 \% .{ }^{1}$ From a household survey of women aged 15-44 years in the United States during the 1990-2011, self-reported pregnancy loss was noted in approximately $20 \%$ of pregnancies with a trend of an increased risk of $1 \%$ per year after excluding maternal factors. ${ }^{2}$ Pregnancy loss includes spontaneous abortion (SAB) or miscarriage defined as fetal death prior to 20 weeks of gestation, and stillbirth defined as fetal death at 20 weeks of gestation or greater. Pregnancy loss can have significant physiologic and psychological consequences for women and families. Identify underlying genetic causes could reduce selfblame among those losing a pregnancy and allow for effective clinical management of future pregnancies. $^{3}$

Genetic abnormalities are known to cause pregnancy loss. Diagnostic karyotyping and microarray analysis identified numerical and structural chromosomal abnormalities and pathogenic copy number variants (pCNVs) in $50 \%$ and $4 \%$ of products of conception (POC) cases, respectively. ${ }^{4}$ Further analysis of these chromosomal abnormalities and pCNVs identified candidate critical genes and potential interactive gene networks affecting early embryonic development. ${ }^{4,5}$ The first report of whole exome sequencing (WES) on a family with recurrent pregnancy loss due to nonimmune hydrops fetalis identified a homozygous rare variant in a highly conserved region of the CHRNA1 gene as a Mendelian cause. ${ }^{6}$ Further application of WES detected relevant alterations in four out of seven cases of fetal demises, ${ }^{7}$ and compound heterozygous mutations in two out of four miscarriages. ${ }^{8}$ More recent WES studies detected positive, possible and candidate variants in 20\%, $45 \%$ and $9 \%$ of 84 fetal death cases with ultrasound anomalies, respectively, ${ }^{9}$ and sequence variants in 15 out of 19 POC cases with missed abortion. ${ }^{10}$ Targeted sequencing on a panel of 70 genes associated with cardiac channelophies and cardiomyopathies detected pathogenic variants in $12 \%$ of 290 cases of stillbirth. ${ }^{11}$ Despite the differences in case selection criteria and inconsistency in variant classification from these studies, accumulated research data indicated that exome sequencing may be instrumental in identifying monogenic causes of a significant portion of pregnancy loss cases and should be integrated into the diagnostic practice. 
medRxiv preprint doi: https://doi.org/10.1101/2020.07.19.20150144; this version posted July 20, 2020. The copyright holder for this preprint (which was not certified by peer review) is the author/funder, who has granted medRxiv a license to display the preprint in perpetuity.

All rights reserved. No reuse allowed without permission.

We performed WES on a cohort of POC samples with normal chromosome and microarray findings. The technical feasibility and sensitivity of this assay were evaluated. Variant classification followed current standards and guidelines developed by the American College of Medical Genetics and Genomics (ACMG) and the Association for Molecular Pathology. ${ }^{12}$ Result interpretation was given by disease association and the possibility of prenatal lethality resulting in pregnancy loss. Approaches to integrate WES into current prenatal diagnosis, genetic counseling and reproduction management were proposed.

\section{MATERIALS AND METHODS}

\section{Ethics Statement}

This study used surplus DNA from POC samples with no personally identifiable private information, it was deemed exempt from ethical oversight and human subject regulations by Yale University Institutional Review Board.

\section{Selection of POC cases}

Specimens of POC were submitted to Yale Clinical Cytogenetics Laboratory. Sequential karyotyping and microarray analyses were performed to detect chromosome abnormalities and pCNVs. ${ }^{13}$ A cohort of 102 cases with normal karyotype and absence of pCNVs collected during 2015 to 2018 were deidentified and selected for WES analysis based on quality and quantity of the leftover DNA. Maternal age, gestational age, clinical indications, gender, and pathologic findings of selected cases were reviewed by a multidisciplinary panel including expertise from Medical Genetics, Obstetrics and Gynecology and Pathology.

\section{Exome sequencing, variant filtering, classification and confirmation}

DNA samples obtained from each case in the cohort were subjected to WES at the Yale Center for Genome Analysis. An initial clinical application of WES estimated the sensitivity for detecting heterozygous variants to be $98 \%$ with mean $40 \mathrm{X}$ sequencing coverage. ${ }^{14}$ A pipeline to assess the pathogenicity and causality of detected variants was validated as previously described $^{15}$ and adopted for current study. Briefly, paired end sequence reads were converted to FASTQ format and were aligned to the reference human genome assembly GRCh37/hg19 
medRxiv preprint doi: https://doi.org/10.1101/2020.07.19.20150144; this version posted July 20, 2020. The copyright holder for this preprint (which was not certified by peer review) is the author/funder, who has granted medRxiv a license to display the preprint in perpetuity.

All rights reserved. No reuse allowed without permission.

(https://genome.ucsc.edu/). Following variant annotation using a Genome Analysis Toolkit (GATK) and AnnoVar, filtering was applied against allele frequencies and disease citations using databases including Genome Aggregation Database (gnomAD, https://gnomad.broadinstitute.org/), an internal database of Yale DNA Diagnostics Laboratory, ClinVAR (https://www.ncbi.nlm.nih.gov/clinvar/), OMIM (https://www.omim.org) and other in silico attributes. Variants with allele frequency above $3 \%$ were excluded from further analysis.

Following ACMG standards and guidelines, the variants with an allele frequency $<3 \%$ were categorized as pathogenic, likely pathogenic, variant of uncertain significance (VUS), likely benign and benign variants. ${ }^{12}$ For this cohort, an additional criterion of VUS favor pathogenic (VUSfp) was applied by in-house rules to include primarily rare missense variants in a gene with a low rate of benign variants and nearby missense variants reported as diseasecausing variants. ${ }^{16}$ Additional deleterious effects of these VUSfp were further analyzed by insilico tools of PolyPhen, SIFT, and CADD. Pathogenic, likely pathogenic and VUSfp were considered variants of diagnostic value. VUSs and benign or likely benign variants were excluded from further analysis. Variants of diagnostic value were verified by Sanger sequencing. Primers flanking the variants for polymerase chain reaction (PCR) are listed in Supplementary Table S1. Purified PCR products were submitted to the Yale DNA sequencing facility for Sanger sequencing. The scheme of variant annotation, filtering and classification is shown in Figure 1.

\section{Assessment of clinical utility and genetic etiology}

Clinical utility of WES for pregnancy loss was assessed by evaluating the abnormality detection rate $(A D R)$ in this cohort. Briefly, the overall ADR was measured as the number of cases with variants of diagnostic value divided by the number of cases analyzed. The ADR in the SAB group (fetal death $<20$ weeks of gestation) was compared to the ADR in the stillbirth group (fetal death $>=20$ weeks of gestation). Proportions of cases with variants of diagnostic value were assessed in different maternal age groups and trimesters of pregnancy. Pathogenicity and causality of variants of diagnostic value were further examined by their OMIM disease association, inheritance mode and disease categories. Furthermore, a list of reference genes and variants was generated to include 147 genes reported in cases of fetal death throughout gestation from a literature search (Supplementary Table S2). ${ }^{6-9,11,17-24}$ Variants of diagnostic value in this 
medRxiv preprint doi: https://doi.org/10.1101/2020.07.19.20150144; this version posted July 20, 2020. The copyright holder for this preprint (which was not certified by peer review) is the author/funder, who has granted medRxiv a license to display the preprint in perpetuity.

All rights reserved. No reuse allowed without permission.

study were compared to the list of reference genes to assess recurrence at either gene level or variant level.

\section{RESULTS}

\section{Clinical Indications and pathologic findings of the POC cases}

Maternal age, gestational age, clinical indications and pathologic findings for these 102 cases were summarized in Supplementary Table S3. The male to female ratio was 49 to 53. The distribution of cases by maternal age groups from age 18-48 years and trimester of pregnancy is shown in Figure $2 \mathrm{a}$ and $2 \mathrm{~b}$. There were 47 cases of SAB, 45 cases of stillbirth, and 10 cases with unknown gestational age (Figure 2c). Approximately 74\% (75/102) of the cases had a maternal age within 26 to 40 years (mean maternal age of 32 years), and 72\% (66/92) of the specimens were from the second trimester (mean gestational age of 19 weeks).

\section{Variants of potential diagnostic value and abnormality detection rate}

Following variant filtering and classification, 39 variants in 36 genes reaching diagnostic value were identified in 36 cases. The six pathogenic variants, 16 likely pathogenic variants, and 17 VUSfp and their OMIM disease association and disease categories are summarized in Tables 1 and 2. Sanger sequencing performed on 26 variants showed $100 \%$ consistency with WES sequence results; representative sequencing results of four variants are shown in Supplementary Figure S1. The ADR as measured by the number of cases with pathogenic or likely pathogenic variants divided by the number of cases analyzed was 22\% (22/102). With the addition of 14 cases with VUSfp, the overall ADR was 35\% (36/102) (Figure 2c). The ADR for SAB was 36\% $(17 / 47)$ and $33 \%$ (15/45) for stillbirth, without statistically significant difference (p-value of 0.78). The proportion of cases with variants of diagnostic value by maternal age groups and by trimester of pregnancy is shown in Figures $2 \mathrm{a}$ and $2 \mathrm{~b}$. The percentage of abnormal cases in maternal ages of 21-25, 26-30, 31-35 and 36-40 years was $17 \%, 37 \%$, $47 \%$ and $38 \%$, respectively. The distribution of paternal ages was not available. The percentage of abnormal cases in first, second and third trimester was 30\%, 38\% and 17\%, respectively. For cases with 
medRxiv preprint doi: https://doi.org/10.1101/2020.07.19.20150144; this version posted July 20, 2020. The copyright holder for this preprint (which was not certified by peer review) is the author/funder, who has granted medRxiv a license to display the preprint in perpetuity.

All rights reserved. No reuse allowed without permission.

variants of diagnostic value, $36 \%$ (13/36) were detected in pregnant women age 35 years or older and at least $69 \%(25 / 36)$ occurred in the second trimester.

\section{Inheritance mode and disease categories}

Among the 39 variants of diagnostic value, 67\% (26/39) were associated with an autosomal dominant (AD) condition, 21\% (8/39) with an autosomal recessive (AR) condition, 10\% (4/39) with a condition that can be either $\mathrm{AD}$ or $\mathrm{AR}$, and $3 \%(1 / 39)$ with an X-linked recessive condition. Four VUSs were also listed in Table 1 as each one of them was found together with one pathogenic or likely pathogenic variant in the same gene. However, the phasing of the VUS and the variant of diagnostic value in the AR gene was undetermined without follow up parental studies. Three cases had variants in more than one gene implicated. Variants associated with dominant conditions had zero to extremely low allele frequency in the general population, and were absent in patients tested for other indications in the Yale DNA Diagnostics Laboratory.

Twelve disease categories were noted for the 36 genes carrying variants of diagnostic value. The most prevalent disease category was multi-system disorders, which included eight genes CHD7, FGFR3, JAG1, TSC2, KIAA1109, TTC21B, FBN1 and NIPBL (2) in nine cases. Additionally, variants in genes SOS1 and SHOC2 of RASopathy, which is a specific group of multi-system disorders, were identified in two cases. The second most common category was cardiac anomalies involving five genes GATA4, DCHS1, SMAD6, MIB1 and CSRP3 in five cases, and arrhythmia involving two genes GPDIL and SCN5A (2) in three cases. Variants in five genes AUST2, FOXP2, SETD5, HACE1 and SYNGAP1 associated with neurodevelopmental disorders were identified in five cases. Variants in five genes $A T P 7 B, C O Q 2, I D S, S M P D 1$ and GFM1 for enzyme and metabolic diseases were noted in five cases. Three cases had variants in genes NPHS1, PKD1 and GREB1L associated with kidney diseases. Variants in genes FGFR2, FGFR3 and COL1A1 associated with skeletal dysplasia were identified in three cases. Variants were also identified in other disease categories including neuropathy $(N E F L)$, myopathy $(N E B)$, coagulation (F11) and CNS abnormality (PIK3R2) in four cases.

Fifteen genes of 17 cases from this cohort, including CHD7, COL1A1, CSRP3, FBN1, FGFR2, FGFR3, GATA4, GPD1L, GREB1L, NIPBL, NPHS1, PIK3R2, SCN5A, SOS1 and TSC2 had been previously reported in separate case series in association with fetal death as listed in 
medRxiv preprint doi: https://doi.org/10.1101/2020.07.19.20150144; this version posted July 20, 2020. The copyright holder for this preprint (which was not certified by peer review) is the author/funder, who has granted medRxiv a license to display the preprint in perpetuity.

All rights reserved. No reuse allowed without permission.

Supplementary Table S2. Among these genes, variants in the FGFR3, SCN5A and NIPBL genes were identified in two cases each within this cohort. This result indicated that $42 \%(15 / 36)$ of the genes involving $47 \%$ (17/36) of cases showed recurring association with fetal death. Recurrence at variant level was also observed in three cases. Variant p.(Gly373Arg) in the PIK3R2 gene of case PL055 with fetal arthrogryposis was previously reported in a fetus with bilateral ventriculomegaly and lissencephaly in a trio-exome study. ${ }^{23}$ Variant p.(Ile124Met) in the GPD1L gene was seen in a SAB case PL058 with single left kidney and two vessel cords; a variant at the same amino acid p.(Ile124Val) was reported in four cases of still birth. ${ }^{11}$ A known pathogenic variant for Thanatophoric dysplasia, p.(Arg248Cys) in the FGFR3 gene identified in case PL067, was reported previously in a case of fetal demise. ${ }^{24}$

\section{DISCUSSION}

Clinical WES was first introduced in 2009 and was adopted quickly as a highly effective approach for postnatal and prenatal genetic diagnosis of Mendelian disorders. ${ }^{14,15,22} \mathrm{~A}$ retrospective analysis of WES on 146 fetuses with ultrasound abnormalities demonstrated a diagnostic rate of $32 \%$ for Mendelian autosomal dominant and recessive disorders. ${ }^{22} \mathrm{~A}$ prospective prenatal exome sequencing analysis of a panel of 1628 genes for developmental disorders on a cohort of 610 fetuses with ultrasound detected structural anomalies showed a diagnostic rate of $12 \%$ for variants of pathogenicity and potential clinical usefulness. ${ }^{24}$ The ADR of this cohort was $22 \%$ for pathogenic and likely pathogenic variants, with an additional $14 \%$ for VUSfp. This diagnostic yield was comparable to the 12\%-32\% from prenatal clinical exome sequencing and the $20 \%-74 \%$ from deceased fetuses with ultrasound anomalies. ${ }^{9}$ The ADR of $36 \%$ from SAB was slightly more than that of $33 \%$ from stillbirth, but the difference was not significant. Combing findings from karyotyping, microarray analysis and WES, the ADR from POC specimens was 50\%, 4\% and 22\%-36\% for chromosomal abnormalities, pCNVs and monogenic variants, respectively. ${ }^{4}$ These results indicated that, with the addition of WES, current genetic testing can identify a specific genetic etiology in about three quarters of the pregnancy loss cases. Since WES can also detect aneuploidies and pCNVs except for rare balanced or derived chromosome rearrangements and low-level mosaicisms, WES could replace routine 
medRxiv preprint doi: https://doi.org/10.1101/2020.07.19.20150144; this version posted July 20, 2020. The copyright holder for this preprint (which was not certified by peer review) is the author/funder, who has granted medRxiv a license to display the preprint in perpetuity.

All rights reserved. No reuse allowed without permission.

cytogenetic evaluations with karyotype and microarray to detect most genetic abnormalities in pregnancy loss.

The challenge in the interpretation of monogenic genetic contributions to pregnancy loss is to clarify disease association and establish cause-effect relationship for fetal death. Recently, accumulated evidence supported causative genetic variants recurring in essential genes involved in embryonic development, organ development and various functions. ${ }^{25-28}$ All the variants of diagnostic value reported in this cohort have a clear association with an OMIM condition. Dominant lethal conditions are poorly understood in humans. In this study, approximately $67 \%$ of the variants of diagnostic value were identified in an AD condition. Actually, two AD conditions were noted in case PL029 with one VUSfp each in the MIB1 and SHOC2 genes and case PL090 with one VUSfp each in the CSRP3 and NIPBL genes. Similarly, case PL037 had one homozygous VUSfp in the TTC21B which is a recessive ciliopathy gene and a VUSfp variant in the SOS1 gene for a dominant RASopathy. It is possible that the variants in both genes act synergistically to result in fetal death. Of the eight cases associated with AR conditions, homozygous pathogenic variants or VUSfps in the SMPD1, ATP7B, HACE1, TTC21B and $C O Q 2$ genes were detected in five cases. While adverse effect on fetal development is more apparent in four genes, $A T P 7 B$ associated Wilson disease as the cause of fetal death will require further evidence. These cases suggested a possible founder effect in the local testing population. Heterozygous variants of likely pathogenic and VUS were detected in the NPHS1, KIAA1109 and $N E B$ genes associated with a AR condition in three cases. Follow up parental study to determine the phase of these variants and functional analysis on gene expression will be necessary to assess their association to fetal death. A very rare VUSfp in the IDS gene associated with X-linked Mucopolysaccharidosis II was identified in a male SAB case; its pathogenicity of glycosaminoglycan accumulation in CNS and other organ systems for fetal death would need further investigation on fetal autopsy. Some of the variants reported are in genes associated with adult onset diseases, such as $F B N 1, P K D 1$ and SMAD6. A variant in the FBN1 gene and a 41-kb deletion containing the TSC 2 and PKD1 genes have been reported in fetuses with ultrasound detected abnormality. ${ }^{22,24}$ These findings raise the possibility that adult onset conditions associated with these genes may have a broader phenotype than we recognized, and could affect fetal development. Likewise, identifying pathogenic variants in genes known to be associated with neurodevelopmental disorders; such as the AUTS2, FOXP2, SETD5 and SYNGAP1 genes, 
medRxiv preprint doi: https://doi.org/10.1101/2020.07.19.20150144; this version posted July 20, 2020. The copyright holder for this preprint

raises a similar possibility of a broader impact of these genes on fetal development. The results from this cohort illustrated that detailed clinicopathologic investigation is needed to determine the cause of fetal death.

Recurrence of certain disease categories and related genes and variants are considered clinical evidence supporting causal effect for pregnancy loss. In this cohort, disease categories showed considerable overlap with those recognized in prior studies including multisystem disorders, cardiovascular abnormalities, urinary system abnormalities, skeletal dysplasia, and central nervous system abnormalities. ${ }^{9,11,22-24}$ Approximately $47 \%$ of the cases in this cohort had evidence supporting the identification of a genetic cause for fetal death from previous studies. Of the 15 recurrent genes, most are associated with multisystem disorders, including the CHD7, FBN1, FGFR3, NIPBL and SOS1 genes; and the second most common ones are associated with cardiac anomalies or arrhythmia including the CSRP3, GATA4, GPDIL and SCN5A genes. The other genes are associated with skeletal dysplasia (COL1A1, FGFR2 and FGFR3), kidney diseases (GREB1L and NPHS1) and CNS abnormality (PIK3R2). More specifically, the variant identified in the PIK3R2 gene, p.(Gly373Arg), is identical to the previously reported PIK3R2 variant, ${ }^{23}$ and a variant causing Thanatophoric dysplasia, p.(Arg248Cys) in the FGFR3 gene, was previously reported in a case of fetal demise. ${ }^{24}$ Variants affecting the same amino acid Ile124 were identified in the GPDIL gene. ${ }^{11}$ Such recurrence at the variant level further supports the important function of certain amino acid positions and protein structure, and that genetic abnormalities at these positions likely contributed to fetal death. The fact that there are recurrent disease categories, genes, and variants found in different studies supports the presence of shared mechanisms and monogenic contributions to pregnancy loss. These results also highlighted that although the genetic etiology underlying pregnancy loss appears to be diverse and heterogenous, some genes may play more critical roles for normal fetal development than others, and fetal development cannot be sustained once these essential genes are deregulated.

There were a few limitations in this study and thus approaches overcoming these limitations should be implemented for clinical use and further research. First, this cohort of 102 cases was adequate to validate the clinical utility of WES but the sample size was insufficient to have a comprehensive evaluation of genetic etiology for pregnancy loss. Given the heterogeneity of disease categories presented in this cohort and other studies, collaborative studies on a large 
medRxiv preprint doi: https://doi.org/10.1101/2020.07.19.20150144; this version posted July 20, 2020. The copyright holder for this preprint (which was not certified by peer review) is the author/funder, who has granted medRxiv a license to display the preprint in perpetuity.

All rights reserved. No reuse allowed without permission.

case series will be needed to investigate the monogenic etiology of fetal death. Second, the samples used for this study were de-identified and follow-up parental study was not pursued. Reanalysis of phase and parental origin of variants could be performed following current ACMG recommendations. ${ }^{29}$ A more complete fetal clinical evaluation combined with a trio study design or a study with follow up parental testing would allow for better assessment of the causality of the variants. Trio analysis has been shown to improve diagnostic yield and variant interpretation over singleton study. ${ }^{9}$ Finally, this study only focused on OMIM genes and was not designed to evaluate non-OMIM genes that might be important for fetal growth and development. Trio study will be critical for discovery of new genes important to fetal development. Furthermore, studies using cellular and animal models should be an integral component of future study design to clarify the functional impact of the identified variants, especially the recurrent and novel variants, on fetal death.

In conclusion, this study demonstrated that $22 \%-35 \%$ of pregnancy losses have variants of diagnostic value in genes that may contribute to fetal death, supporting the use of WES as a valuable genetic testing tool in identifying a cause for pregnancy loss. Identification of recurrent genes and variants associated with fetal death may lead to better understanding of the functions of known OMIM genes in fetal development and their roles in pregnancy loss. Identification of variants of diagnostic value provides necessary information for recurrence risk assessment, follow up parental studies, prenatal genetic counseling, and management of subsequent pregnancies.

\section{SUPPLEMENTARY MATERIALS}

The online version of this article contains supplementary figure S1 and supplementary tables S1, S2 and S3.

\section{DISCLOSURE}

All authors read and approved the manuscript and declare that they have no conflict of interest.

\section{REFERENCENS}

1. Wilcox AJ, Weinberg CR, O'Connor JF, et al. Incidence of early loss of pregnancy. N Engl J Med. 1988;319:189 $\square 194$. 
medRxiv preprint doi: https://doi.org/10.1101/2020.07.19.20150144; this version posted July 20, 2020. The copyright holder for this preprint

2. Rossen LM, Ahrens KA, Branum AM. Trends in Risk of Pregnancy Loss Among US Women, 1990-2011. Paediatr Perinat Epidemiol. 2018;32:19 $\square 29$.

3. Nikcevic AV, Tunkel SA, Kuczmierczyk AR, Nicolaides KH. Investigation of the cause of miscarriage and its influence on women's psychological distress. Br J Obstet Gynaecol. 1999; 106:808卬813.

4. Zhou Q, Wu S-Y, Amato K, Diadamo A, Li P. Spectrum of cytogenomic abnormalities revealed by array comparative genomic hybridization in products of conception culture failure and normal karyotype samples. J Genet Genomics. 2016;43:121-131.

5. Chen Y, Bartanus J, Liang D, et al. Characterization of chromosomal abnormalities in pregnancy losses reveals critical genes and loci for human early development. Hum Mutat. 2017;38:669 $\square 677$.

6. Shamseldin HE, Swaid A, Alkuraya FS. Lifting the lid on unborn lethal Mendelian phenotypes through exome sequencing. Genet Med. 2013;15:307 $\square 309$.

7. Alamillo CL, Powis Z, Farwell K, et al. Exome sequencing positively identified relevant alterations in more than half of cases with an indication of prenatal ultrasound anomalies. Prenat Diagn. 2015;35:1073-1078.

8. Qiao Y, Wen J, Tang F, et al. Whole exome sequencing in recurrent early pregnancy loss. Mol Hum Reprod. 2016;22:364ø372.

9. Yates CL, Monaghan KG, Copenheaver D, et al. Whole-exome sequencing on deceased fetuses with ultrasound anomalies: expanding our knowledge of genetic disease during fetal development. Genet Med. 2017;19:1171-1178.

10. Fu M, Mu S, Wen C, et al. Whole-exome sequencing analysis of products of conception identifies novel mutations associated with missed abortion. Mol Med Rep. 2018;18:2027 $\square 2032$.

11. Sahlin E, Gréen A, Gustavsson P, et al. Identification of putative pathogenic single nucleotide variants (SNVs) in genes associated with heart disease in 290 cases of stillbirth. PLoS One. 2019;14:e0210017.

12. Richards S, Aziz N, Bale S, et al. Standards and guidelines for the interpretation of sequence variants: a joint consensus recommendation of the American College of Medical Genetics and Genomics and the Association for Molecular Pathology. Genet Med. 2015;17:405 $\square 424$.

13. Li P, Pomianowski P, DiMaio MS, et al. Genomic characterization of prenatally detected chromosomal structural abnormalities using oligonucleotide array comparative genomic hybridization. Am J Med Genet A. 2011;155A:1605 $\square 1615$.

14. Choi M, Scholl UI, Ji W, et al. Genetic diagnosis by whole exome capture and massively parallel DNA sequencing. Proc Natl Acad Sci U S A. 2009;106:19096 $\square 19101$.

15. Seidelmann SB, Smith E, Subrahmanyan L, et al. Application of whole exome sequencing in the clinical diagnosis and management of inherited cardiovascular diseases in adults. Circ Cardiovasc Genet. 2017;10:e001573. 
medRxiv preprint doi: https://doi.org/10.1101/2020.07.19.20150144; this version posted July 20, 2020. The copyright holder for this preprint (which was not certified by peer review) is the author/funder, who has granted medRxiv a license to display the preprint in perpetuity.

All rights reserved. No reuse allowed without permission.

16. Hoskinson DC, Dubuc AM, Mason-Suares H. The current state of clinical interpretation of sequence variants. Curr Opin Genet Dev. 2017;42:33-39.

17. Ovunc B, Ashraf S, Vega-Warner V, et al. Mutation analysis of NPHS1 in a worldwide cohort of congenital nephrotic syndrome patients. Nephron Clin Pract. 2012;120:139-146.

18. Crotti L, Tester DJ, White WM, et al. Long QT syndrome-associated mutations in intrauterine fetal death. JAMA. 2013;309:1473 $\square 1482$.

19. Boissel S, Fallet-Bianco C, Chitayat D, et al. Genomic study of severe fetal anomalies and discovery of GREB1L mutations in renal agenesis. Genet Med. 2018;20:745-753.

20. Datkhaeva I, Arboleda VA, Senaratne TN, et al. Identification of novel PIEZO1 variants using prenatal exome sequencing and correlation to ultrasound and autopsy findings of recurrent hydrops fetalis. Am J Med Genet A. 2018;176:2829 $\square 2834$.

21. Munroe PB, Addison S, Abrams DJ, et al. Postmortem Genetic Testing for Cardiac Ion Channelopathies in Stillbirths. Circ Genom Precis Med. 2018;11:e001817.

22. Normand EA, Braxton A, Nassef S, et al. Clinical exome sequencing for fetuses with ultrasound abnormalities and a suspected Mendelian disorder. Genome Med. 2018;10:74.

23. Quinlan-Jones E, Lord J, Williams D, et al. Molecular autopsy by trio exome sequencing (ES) and postmortem examination in fetuses and neonates with prenatally identified structural anomalies. Genet Med. 2019;21:1065 $\square 1073$.

24. Lord J, McMullan DJ, Eberhardt RY, et al. Prenatal exome sequencing analysis in fetal structural anomalies detected by ultrasonography (PAGE): a cohort study. Lancet. 2019;393:747 $\square 757$.

25. Filges I, Friedman JM. Exome sequencing for gene discovery in lethal fetal disorders-harnessing the value of extreme phenotypes. Prenat Diagn. 2015;35:1005 $\square 1009$.

26. Colley E, Hamilton S, Smith P, Morgan NV, Coomarasamy A, Allen S. Potential genetic causes of miscarriage in euploid pregnancies: a systematic review. Hum Reprod Update. 2019;25:452 $\square 472$.

27. Robbins SM, Thimm MA, Valle D, Jelin AC. Genetic diagnosis in first or second trimester pregnancy loss using exome sequencing: a systematic review of human essential genes. J Assist Reprod Genet. 2019;36:1539 $\square 1548$.

28. Rajcan-Separovic E. Next generation sequencing in recurrent pregnancy loss-approaches and outcomes. Eur J Med Genet. 2020;63:103644.

29. Deignan JL, Chung WK, Kearney HM, et al. Points to consider in the reevaluation and reanalysis of genomic test results: a statement of the American College of Medical Genetics and Genomics (ACMG). Genet Med. 2019;21:1267 $\square 1270$. 


\section{Figure Legends}

Figure 1 A scheme for variant annotation, filtering and classification. Variants classified as pathogenic, likely pathogenic and VUSfp were considered diagnostic for pregnancy loss.

Figure 2 Clinical demographics for the 102 POC cases. A) Distribution of cases by maternal age (open bar) and cases with variants of diagnostic value (shade bar), B) Distribution of case by gestational trimesters (open bar) and cases with variant of diagnostic value (shade bar), C)

Number of cases in SAB, stillbirth and unknown gestational ages and ADR for overall cases and for cases of SAB and stillbirth. (uk, unknown; ADR, abnormality detection rate; P/LP pathogenic/likely pathogenic; VUSfp, variants of uncertain significance favor pathogenic, NL normal). 


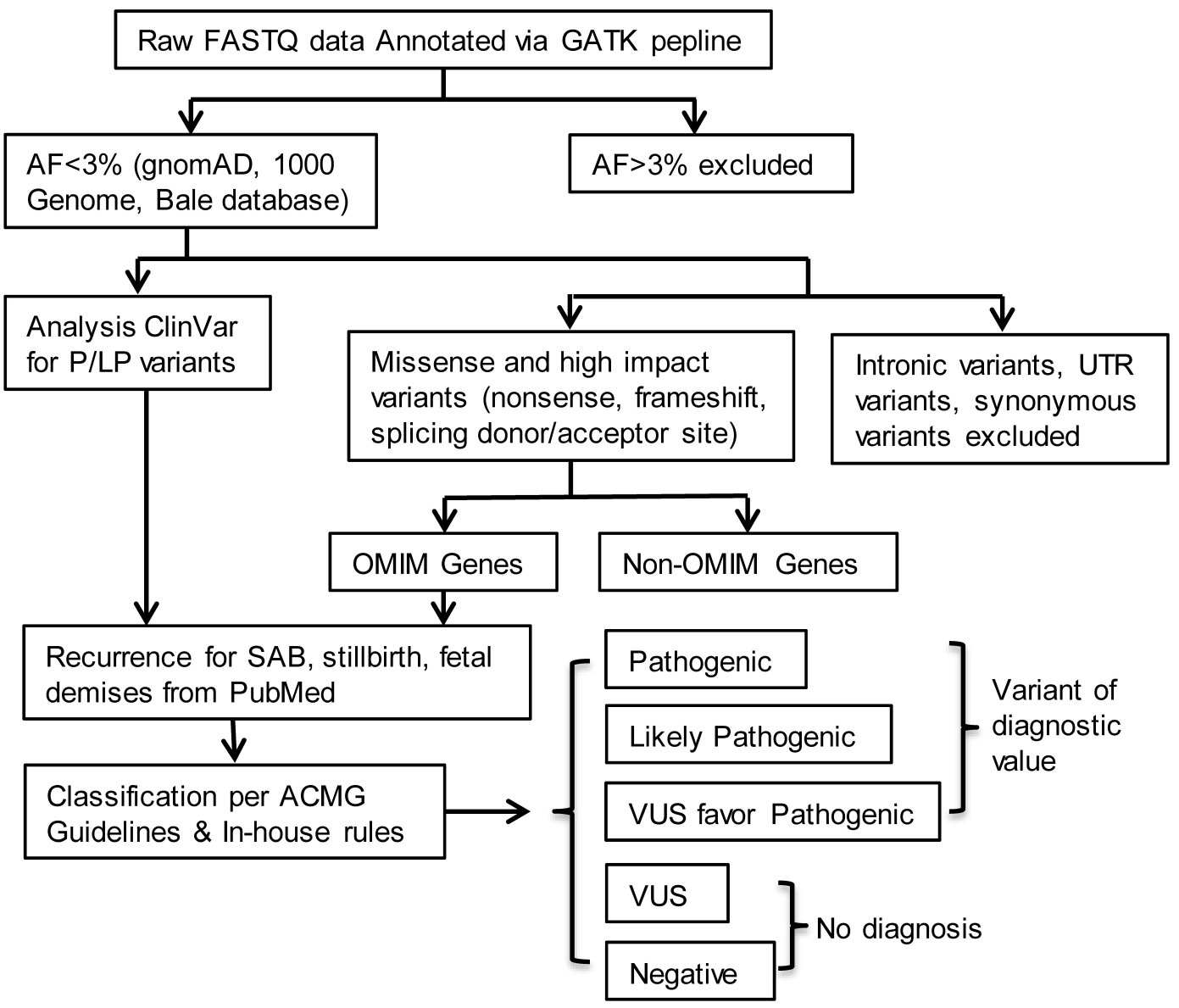




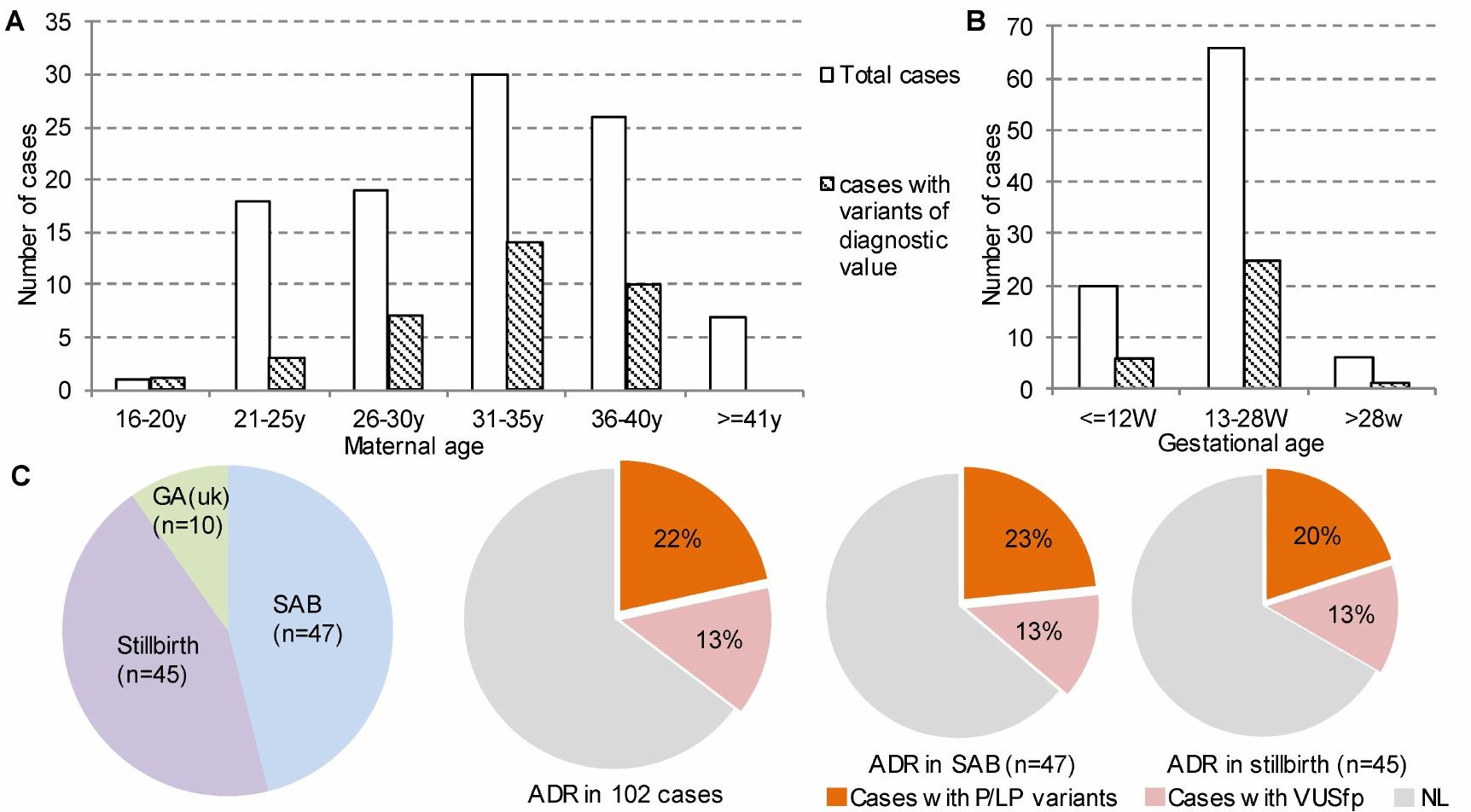


Table 1 Pathogenic and likely pathogenic variants detected in this study*

\begin{tabular}{|c|c|c|c|c|c|c|c|c|c|c|}
\hline $\begin{array}{l}\text { Case } \\
\text { ID }\end{array}$ & Indications & $\begin{array}{l}\text { Gestation } \\
\text { al age } \\
\text { (wks) }\end{array}$ & Gene & Variant & $\begin{array}{l}\text { Zygos } \\
\text { ity }\end{array}$ & $\begin{array}{l}\text { AF } \\
\text { (gnomAD) }\end{array}$ & $\begin{array}{l}\text { Type of } \\
\text { Variant }\end{array}$ & $\begin{array}{l}\text { ACMG } \\
\text { Classifi } \\
\text { cation }\end{array}$ & $\begin{array}{l}\text { OMIM Diseases \& } \\
\text { Inheritance }\end{array}$ & $\begin{array}{l}\text { Diseasae } \\
\text { Category }\end{array}$ \\
\hline \multirow[t]{2}{*}{ PL001 } & \multirow[t]{2}{*}{ fetal demise } & \multirow[t]{2}{*}{$215 / 7$} & \multirow[t]{2}{*}{ NPHS1 } & $\begin{array}{l}\text { NM_004646:c.2905delC, } \\
\text { p.(Leu969Cysfs*32) }\end{array}$ & Het & $1 / 30938$ & FS & LP & \multirow{2}{*}{$\begin{array}{l}\text { Nephrotic } \\
\text { syndrome, type } 1 ; \\
\text { AR }\end{array}$} & \multirow[t]{2}{*}{$\begin{array}{l}\text { Kidney } \\
\text { disease }\end{array}$} \\
\hline & & & & NM_004646:c.3110-5C>T & Het & $1 / 6929$ & SpR & VUS & & \\
\hline PL003 & $\begin{array}{l}\text { fetal } \\
\text { anomaly }\end{array}$ & $222 / 7$ & NEFL & $\begin{array}{l}\text { NM_006158:c.493G>T, } \\
\text { p.(Glu165*) }\end{array}$ & Het & 0 & Non & LP & $\begin{array}{l}\text { Charcot-Marie- } \\
\text { Tooth disease, type } \\
\text { 1F; AD/AR }\end{array}$ & Neuropathy \\
\hline PL006 & $\begin{array}{l}\text { fetal } \\
\text { anomaly of } \\
\text { cystic } \\
\text { hygroma }\end{array}$ & 11 & CHD7 & $\begin{array}{l}\text { NM_017780:c.5428C>T, } \\
\text { p.(Arg1810*) }\end{array}$ & Het & 0 & Non & LP & $\begin{array}{l}\text { CHARGE } \\
\text { syndrome; } \mathrm{AD}\end{array}$ & Multi-system \\
\hline \multirow[t]{2}{*}{ PL024 } & \multirow[t]{2}{*}{$\begin{array}{l}\text { fetal } \\
\text { anomaly }\end{array}$} & \multirow[t]{2}{*}{$205 / 7$} & \multirow[t]{2}{*}{ GFM1 } & $\begin{array}{l}\text { NM_024996:c.914delG, } \\
\text { p.(Gly305Glufs*6) }\end{array}$ & Het & 0 & FS & LP & \multirow{2}{*}{$\begin{array}{l}\text { Combined } \\
\text { oxidative } \\
\text { phosphorylation } \\
\text { deficiency 1; AR }\end{array}$} & \multirow[t]{2}{*}{$\begin{array}{l}\text { Enzyme/Meta } \\
\text { bolic }\end{array}$} \\
\hline & & & & $\begin{array}{l}\text { NM_024996:c.1865A>G, } \\
\text { p.(Asn622Ser) }\end{array}$ & Het & $1 / 141341$ & Mis & VUS & & \\
\hline PL031 & fetal demise & unknown & DCHS1 & $\begin{array}{l}\text { NM_003737:c.6421C>T, } \\
\text { p.(Arg2141*) }\end{array}$ & Het & 0 & Non & LP & $\begin{array}{l}\text { Van Maldergem } \\
\text { syndrome 1, AR; } \\
\text { Mitral Valve } \\
\text { Prolapse 2; AD }\end{array}$ & $\begin{array}{l}\text { Cardiac } \\
\text { anomaly }\end{array}$ \\
\hline PL033 & fetal demise & unknown & PKD1 & $\begin{array}{l}\text { NM_001009944:c.12124C>T } \\
\text {,p.(Gln4042*) }\end{array}$ & Het & 0 & Non & $\mathrm{P}$ & $\begin{array}{l}\text { Polycystic kidney } \\
\text { disease } 1 ; \mathrm{AD}\end{array}$ & $\begin{array}{l}\text { Kidney } \\
\text { disease }\end{array}$ \\
\hline PL043 & $\begin{array}{l}\text { missed } \\
\text { abortion }\end{array}$ & $83 / 7$ & AUTS2 & $\begin{array}{l}\text { NM_015570:c.53C>A, } \\
\text { p.(Ser18*) }\end{array}$ & Het & 0 & Non & LP & $\begin{array}{l}\text { Mental retardation, } \\
\text { autosomal } \\
\text { dominant } 26 ; \mathrm{AD}\end{array}$ & $\begin{array}{l}\text { Neurodevelop } \\
\text { mental } \\
\text { disorder }\end{array}$ \\
\hline PL048 & fetal demise & 15 & GATA4 & $\begin{array}{l}\text { NM_002052:c.1325C>T, } \\
\text { p.(Ala442Val) }\end{array}$ & Het & $1 / 62871$ & Mis & LP & $\begin{array}{l}\text { GATA4-associated } \\
\text { heart disease } \\
\text { (OMIM:600576), } \\
\text { AD }\end{array}$ & $\begin{array}{l}\text { Cardiac } \\
\text { anomaly }\end{array}$ \\
\hline PL052 & $\begin{array}{l}\text { missed } \\
\text { abortion }\end{array}$ & $104 / 7$ & FGFR3 & $\begin{array}{l}\text { NM_000142:c.1537G>T, } \\
\text { p.(Asp513Tyr) }\end{array}$ & Het & 0 & Mis & LP & $\begin{array}{l}\text { LADD syndrome; } \\
\text { AD }\end{array}$ & Multi-system \\
\hline PL055 & $\begin{array}{l}\text { fetal } \\
\text { anomaly }\end{array}$ & $224 / 7$ & PIK3R2 & $\begin{array}{l}\text { NM_005027:c.1117G >A, } \\
\text { p.(Gly373Arg) }\end{array}$ & Het & 0 & Mis & $\mathrm{P}$ & $\begin{array}{l}\text { Megalencephaly- } \\
\text { polymicrogyria- } \\
\text { polydactyly- } \\
\text { hydrocephalus } \\
\text { syndrome } 1 ; \text { AD }\end{array}$ & $\begin{array}{l}\text { CNS } \\
\text { abnomality }\end{array}$ \\
\hline
\end{tabular}




\begin{tabular}{|c|c|c|c|c|c|c|c|c|c|c|}
\hline PL057 & $\begin{array}{l}\text { fetal } \\
\text { anomaly }\end{array}$ & $133 / 7$ & SMPD1 & $\begin{array}{l}\text { NM_000543:c.1133G>A, } \\
\text { p.(Arg378His) }\end{array}$ & Homo & $1 / 14029$ & Mis & $\mathrm{P}$ & $\begin{array}{l}\text { Niemann-Pick } \\
\text { disease, type A/B ; } \\
\text { AR }\end{array}$ & $\begin{array}{l}\text { Enzyme/meta } \\
\text { bolic }\end{array}$ \\
\hline PL058 & $\begin{array}{l}\text { fetal } \\
\text { anomaly }\end{array}$ & $194 / 7$ & GPD1L & $\begin{array}{l}\text { NM_015141:c.372A>G, } \\
\text { p.(Ile124Met) }\end{array}$ & Het & $1 / 20196$ & Mis & LP & $\begin{array}{l}\text { Brugada syndrome } \\
2 ; \mathrm{AD}\end{array}$ & Arrhythmia \\
\hline PL059 & fetal demise & 26 & F11 & NM_000128.3:c.1716+1G>A & Het & $1 / 125746$ & $\mathrm{SpD}$ & $\mathrm{P}$ & $\begin{array}{l}\text { Factpr XI } \\
\text { deficiency; AD/AR }\end{array}$ & Coagulation \\
\hline PL060 & Spina bifida & 19 & FOXP2 & NM_014491.3:c.258+1G>A & Het & $1 / 250396$ & $\mathrm{SpD}$ & LP & $\begin{array}{l}\text { Speech-language } \\
\text { disorder-1; AD }\end{array}$ & $\begin{array}{l}\text { Neurodevelop } \\
\text { mental } \\
\text { disorder }\end{array}$ \\
\hline PL061 & fetal demise & 32 & SETD5 & $\begin{array}{l}\text { NM_001080517:c.4106dupT, } \\
\text { p.(Ser1370Glufs*10) }\end{array}$ & Het & $1 / 124629$ & FS & LP & $\begin{array}{l}\text { Mental retardation, } \\
\text { autosomal } \\
\text { dominant } 23 \text {; AD }\end{array}$ & $\begin{array}{l}\text { Neurodevelop } \\
\text { mental } \\
\text { disorder }\end{array}$ \\
\hline PL066 & fetal demise & 26 & ATP7B & $\begin{array}{l}\text { NM_000053:c.3207C>A, } \\
\text { p.(His1069Gln) }\end{array}$ & Homo & $1 / 1981$ & Mis & $\mathrm{P}$ & $\begin{array}{l}\text { Wilson Disease; } \\
\text { AR }\end{array}$ & $\begin{array}{l}\text { Enzyme/Meta } \\
\text { bolic }\end{array}$ \\
\hline PL067 & $\begin{array}{l}\text { Skeletal } \\
\text { dysplasia }\end{array}$ & 20 & FGFR3 & $\begin{array}{l}\text { NM_000142:c.742C>T, } \\
\text { p.(Arg248Cys) }\end{array}$ & Het & 0 & Mis & $\mathrm{P}$ & $\begin{array}{l}\text { Thanatophoric } \\
\text { dysplasia, type I ; } \\
\text { AD }\end{array}$ & $\begin{array}{l}\text { Skeletal } \\
\text { dysplasia }\end{array}$ \\
\hline PL072 & fetal demise & 22 & SCN5A & $\begin{array}{l}\text { NM_198056:c.5393G>A, } \\
\text { p.(Trp1798*) }\end{array}$ & Het & 0 & Non & LP & $\begin{array}{l}\text { SCN5A-associated } \\
\text { cardiac diseases, } \\
\text { AD }\end{array}$ & Arrhythmia \\
\hline PL073 & $\begin{array}{l}\text { fetal } \\
\text { anomaly }\end{array}$ & $186 / 7$ & $\begin{array}{l}\text { GREB1 } \\
\mathrm{L}\end{array}$ & $\begin{array}{l}\text { NM_001142966:c.1305dupA, } \\
\text { p.(Asp436Argfs*32) }\end{array}$ & Het & 0 & FS & LP & $\begin{array}{l}\text { Renal } \\
\text { hypodysplasia/apla } \\
\text { sia 3; AD }\end{array}$ & $\begin{array}{l}\text { Kidney } \\
\text { disease }\end{array}$ \\
\hline PL076 & $\begin{array}{l}\text { embryonic } \\
\text { demise }\end{array}$ & 7 & SMAD6 & $\begin{array}{l}\text { NM_005585:c.652C>T, } \\
\text { p.(Gln218*) }\end{array}$ & Het & 0 & Non & LP & $\begin{array}{l}\text { Aortic Valve } \\
\text { Disease, AD }\end{array}$ & $\begin{array}{l}\text { Cardiac } \\
\text { anomaly }\end{array}$ \\
\hline \multirow[t]{2}{*}{ PL078 } & \multirow[t]{2}{*}{ fetal demise } & \multirow[t]{2}{*}{16} & \multirow[t]{2}{*}{$\begin{array}{l}\text { KIAA11 } \\
09\end{array}$} & $\begin{array}{l}\text { NM_015312:c.3986A>G, } \\
\text { p.(Tyr1329Cys) }\end{array}$ & Het & $1 / 31209$ & Mis & LP & \multirow{2}{*}{$\begin{array}{l}\text { Alkuraya- } \\
\text { Kucinskas } \\
\text { syndrome; AR }\end{array}$} & \multirow[t]{2}{*}{ Multi-system } \\
\hline & & & & $\begin{array}{l}\text { NM_015312:c. } 11093 C>G, \\
\text { p.(Ser3698Cys) }\end{array}$ & Het & $1 / 69995$ & Mis & VUS & & \\
\hline \multirow[t]{2}{*}{ PL088 } & \multirow[t]{2}{*}{$\begin{array}{l}\text { fetal } \\
\text { anomaly }\end{array}$} & \multirow[t]{2}{*}{18} & \multirow[t]{2}{*}{ NEB } & $\begin{array}{l}\text { NM_001271208:c.24094C>T } \\
\text {,p.(Arg8032*) }\end{array}$ & Het & $1 / 2052$ & Non & LP & \multirow[t]{2}{*}{$\begin{array}{l}\text { Nemaline } \\
\text { myopathy } 2, \mathrm{AR}\end{array}$} & \multirow[t]{2}{*}{ Myopathy } \\
\hline & & & & $\begin{array}{l}\text { NM_001271208:c.20098C>A } \\
\text {,p.(Leu6700Ile) }\end{array}$ & Het & $1 / 2336$ & Mis & VUS & & \\
\hline
\end{tabular}

* AF: Allele Frequency, Het: Heterozygous, Homo: Homozygous, Non: Nonsense, Mis: Missense, FS: Frameshift, SpR: Splicing receptor site, SpD: Splicing donor site, P: Pathogenic, LP: Likely pathogenic, AD: autosomal dominant inheritance, AR: autosomal recessive inheritance. 
Table 2 Variants of uncertain significance favor pathogenic detected in this study*

\begin{tabular}{|c|c|c|c|c|c|c|c|c|c|}
\hline $\begin{array}{l}\text { Case } \\
\text { ID }\end{array}$ & Indications & $\begin{array}{l}\text { Gestation } \\
\text { al age } \\
(\text { wks) }\end{array}$ & Gene & Variant & Zygosity & $\begin{array}{l}\text { AF } \\
(\text { gnomAD) }\end{array}$ & $\begin{array}{l}\text { Type of } \\
\text { Variant }\end{array}$ & $\begin{array}{l}\text { OMIM Diseases \& } \\
\text { Inheritance }\end{array}$ & $\begin{array}{l}\text { Diseasae } \\
\text { Category }\end{array}$ \\
\hline PL005 & fetal demise & 13 & FGFR2 & $\begin{array}{l}\text { NM_000141:c.182G>A, } \\
\text { p.(Arg61His) }\end{array}$ & Het & $1 / 61546$ & Mis & $\begin{array}{l}\text { FGFR2-realted } \\
\text { syndrome, AD }\end{array}$ & $\begin{array}{l}\text { Skeletal } \\
\text { dysplasia }\end{array}$ \\
\hline PL019 & $\begin{array}{l}\text { Fetal demise, } \\
\text { mutiple } \\
\text { anomalies }\end{array}$ & $224 / 7$ & FBN1 & $\begin{array}{l}\text { NM_000138:c.7999G>A, } \\
\text { p.(Glu2667Lys) }\end{array}$ & Het & $1 / 30250$ & Mis & $\begin{array}{l}\text { Marfan syndrome } \\
\text { AD }\end{array}$ & Multi-system \\
\hline \multirow[t]{2}{*}{ PL029 } & \multirow[t]{2}{*}{$\begin{array}{l}\text { embryonic } \\
\text { demise }\end{array}$} & \multirow[t]{2}{*}{10} & MIB1 & $\begin{array}{l}\text { NM_020774:c.351dupA, } \\
\text { p.(His118Thrfs*16) }\end{array}$ & Het & 0 & FS & $\begin{array}{l}\text { Left ventricular } \\
\text { noncompaction } 7 \text {; } \\
\text { AD }\end{array}$ & $\begin{array}{l}\text { Cardiac } \\
\text { anomaly }\end{array}$ \\
\hline & & & SHOC2 & $\begin{array}{l}\text { NM_007373:c.241A>G, } \\
\text { p.(Thr81Ala) }\end{array}$ & Het & $1 / 35826$ & Mis & $\begin{array}{l}\text { Noonan syndrome- } \\
\text { like with loose } \\
\text { anagen hair; AD }\end{array}$ & Rasopathy \\
\hline PL032 & fetal demise & 22 & HACE1 & $\begin{array}{l}\text { NM_020771:c.212T }>C, \\
\text { p.(Ile71Thr) }\end{array}$ & Homo & 0 & Mis & $\begin{array}{l}\text { Spastic paraplegia } \\
\text { and psychomotor } \\
\text { retardation with or } \\
\text { without seizures; } \\
\text { AR }\end{array}$ & $\begin{array}{l}\text { Neurodevel } \\
\text { opmental } \\
\text { disorder }\end{array}$ \\
\hline PL034 & $\begin{array}{l}\text { missed } \\
\text { abortion }\end{array}$ & 18 & NIPBL & $\begin{array}{l}\text { NM_133433:c.1927A>G, } \\
\text { p.(Lys643Glu) }\end{array}$ & Het & 0 & Mis & $\begin{array}{l}\text { Cornelia de Lange } \\
\text { syndrome } 1 ; \mathrm{AD}\end{array}$ & Multi-system \\
\hline \multirow[t]{2}{*}{ PL037 } & \multirow[t]{2}{*}{ fetal demise } & \multirow[t]{2}{*}{ unknown } & SOS1 & $\begin{array}{l}\text { NM_005633:c.205G>A, } \\
\text { p.(Asp69Asn) }\end{array}$ & Het & 0 & Mis & $\begin{array}{l}\text { Noonan Syndrom 4; } \\
\text { AD }\end{array}$ & Rasopathy \\
\hline & & & TTC21B & $\begin{array}{l}\text { NM_024753:c.511G>A, } \\
\text { p.(Gly171Arg) }\end{array}$ & Homo & $1 / 3400$ & Mis & $\begin{array}{l}\text { Short-rib thoracic } \\
\text { dysplasia } 4 \text { with or } \\
\text { without polydactyly; } \\
\text { AR }\end{array}$ & Multi-system \\
\hline PL038 & $\begin{array}{l}\text { missed } \\
\text { abortion, } \\
\text { fetal } \\
\text { anomalies }\end{array}$ & $236 / 7$ & TSC2 & NM_000548.3:c.1946+5G>T & Het & 0 & SpR & $\begin{array}{l}\text { Tuberous sclerosis-2; } \\
\text { AD }\end{array}$ & Multi-system \\
\hline PL039 & fetal demise & $212 / 7$ & SYNGAP1 & $\begin{array}{l}\text { NM_006772:c.773G>A, } \\
\text { p.(Arg258His) }\end{array}$ & Het & $1 / 81822$ & Mis & $\begin{array}{l}\text { Mental retardation, } \\
\text { autosomal dominant } \\
\text { 5; AD }\end{array}$ & $\begin{array}{l}\text { Neurodevelo } \\
\text { pmental } \\
\text { disorder }\end{array}$ \\
\hline PL071 & fetal anomaly & 21 & COQ2 & $\begin{array}{l}\text { NM_015697:c.662T }>C, \\
\text { p.(Leu221Pro) }\end{array}$ & Homo & $1 / 124388$ & Mis & $\begin{array}{l}\text { Coenzyme Q10 } \\
\text { deficiency, primary, } \\
1 \text {; AR }\end{array}$ & $\begin{array}{l}\text { Enzyme/Met } \\
\text { abolic }\end{array}$ \\
\hline
\end{tabular}




\begin{tabular}{|c|c|c|c|c|c|c|c|c|c|}
\hline PL075 & PRROM & $205 / 7$ & SCN5A & $\begin{array}{l}\text { NM_198056:c.1933T }>G \text {, } \\
\text { p.(Ser645Ala) }\end{array}$ & Het & 0 & Mis & $\begin{array}{l}\text { SCN5A related } \\
\text { disorders; AD/AR }\end{array}$ & Arrhythmia \\
\hline PL080 & fetal demise & unknown & JAG1 & $\begin{array}{l}\text { NM_000214:c.218C>G, } \\
\text { p.(Thr73Arg) }\end{array}$ & Het & 0 & Mis & $\begin{array}{l}\text { Alagille syndrome 1, } \\
\text { AD; Tetralogy of } \\
\text { Fallot, AD }\end{array}$ & Multi-system \\
\hline PL083 & fetal demise & $143 / 7$ & IDS & $\begin{array}{l}\text { NM_000202:c.778C >T, } \\
\text { p.(Pro260Ser) }\end{array}$ & Hemi & 0 & Mis & $\begin{array}{l}\text { Mucopolysaccharidos } \\
\text { is II; XLR }\end{array}$ & $\begin{array}{l}\text { Enzyme/Met } \\
\text { abolic }\end{array}$ \\
\hline \multirow[t]{2}{*}{ PL090 } & \multirow[t]{2}{*}{ fetal demise } & \multirow[t]{2}{*}{$113 / 7$} & CSRP3 & NM_003476:c.3G>A, p.? & Het & 0 & SL & $\begin{array}{l}\text { Cardiomyopathy, } \\
\text { dilated, 1M ; AD }\end{array}$ & $\begin{array}{l}\text { Cardiac } \\
\text { anomaly }\end{array}$ \\
\hline & & & NIPBL & $\begin{array}{l}\text { NM_133433:c.193C>G, } \\
\text { p.(Leu65Val) }\end{array}$ & Het & 0 & Mis & $\begin{array}{l}\text { Cornelia de Lange } \\
\text { syndrome } 1 ; \mathrm{AD}\end{array}$ & Multi-system \\
\hline PL094 & fetal demise & $151 / 7$ & COL1A1 & $\begin{array}{l}\text { NM_000088:c.4024G>A, } \\
\text { p.(Gly1342Ser) }\end{array}$ & Het & $1 / 81771$ & Mis & $\begin{array}{l}\text { Osteogenesis } \\
\text { imperfecta I; AD }\end{array}$ & $\begin{array}{l}\text { Skeletal } \\
\text { dysplasia }\end{array}$ \\
\hline
\end{tabular}

* AF: Allele Frequency, Het: Heterozygous, Homo: Homozygous, Hemi: Hemizygous, Mis: Missense, FS: Frameshift, SpR: Splicing receptor, SL: StartLoss, AD: autosomal dominant inheritance, AR: autosomal recessive inheritance. 